\title{
Comparative Analysis of Women's Rights and Post-Marriage Nationality
}

\author{
Sentot Ahangaran; Fitriani Pitoyo \\ Faculty of Law, Universitas Sebelas Maret, Indonesia \\ ria_ans,soc11@koyauniversity.org
}

\begin{abstract}
In the nineteenth century, a school known as "The Unity System of Couples Nationality" expressed that women ought to obtain the nationality of their spouses after marriage. In different words, the nationality of men ought to be forced on women. In any case, in the twentieth century, a development known as woman's rights developed which prompted the arrangement of a school named "Arrangement of Nationality Independence".

This school supported the partition of marriage and nationality and accepted that women's nationality ought not to change following marriage. The previously mentioned legitimate schools have had various indications in the positive laws of various nations and some of the time it is difficult to order them into a single lawful school. The lawful frameworks of nations can be ordered into two gatherings: lawful frameworks upholding the burden of spouses' nationality on spouses; lawful frameworks restricting the inconvenience of spouses' nationality on wives.
\end{abstract}

Keyword: Nationality; Marriage; Legal systems

\section{Introduction}

The accentuation on the thought of nationality began was when fringes presented the idea of free government to the world. From that point, forward governments have attempted to acquaint their nationals so as with strengthen their feeling of predominance. Nationality is a blend of political, legitimate and profound relations that make a connection between an individual and an administration. The nationality with which a youngster is conceived is designated "essential nationality". Essential nationality proceeds over the individual's life except if it is changed deliberately or accidentally.

As a man and woman with a similar nationality may wed one another, a woman and a man with two distinct nationalities may likewise go into marriage. The issue of marriage between a man and a woman with two unique nationalities has consistently prompted the inquiry that whether it is important to force the nationality of one on another or whether they are allowed to live respectively with various nationalities. Another inquiry is: if the hitched life requires the solidarity of nationality, is it important to give lawful offices so one can get the nationality of another legislature by requesting the nationality of that ideal government? A few researchers accept that family is a solitary unit and accordingly to guarantee the solidarity of family the couples associated with it must have a solitary nationality. Consequently, they force 
spouse's nationality to the wife. Then again, women's activists contradict the inconvenience of men's nationality on women and stress the uniformity of rights for people. Subsequently, it is critical to consider the nationality of a woman who weds a remote man in light of the fact that the national enactment of the goal nation may force man's nationality on the woman or it may give the woman the privilege to pick her better half's nationality. It may likewise have faith in the autonomy of nationality of women and men. There are various perspectives on this issue and various enactments have moved toward it with various standards and guidelines. These distinctions are tended to in the accompanying.

\section{Discussion}

Preceding the twentieth century and since the start of the 21 st century, legal advisers have constantly focused on the issue of nationality and have expressed that conjugal connections cannot be governed by more than one national law. Thus, it is important to guarantee solidarity of nationality by any potential methods. Nevertheless, this standard applies to a nation that applies the national couple's law to individual issues. In this way, in nations that apply the living arrangement rule to the individual issues, solidarity of nationality has no viable use (Azimzadeh and Khosravi, 2009).

The benefit of solidarity of nationality is that the rights and obligations of couples are characterized and deciphered in one lawful framework in light of the fact that in numerous nations, individual undertakings are affected by national law and consequently if the husband and spouse are affected by two distinct guidelines opposing commitments are forced on them and the entire family is beset. It can even destroy the wedded existence of these couples. Despite this preferred position, there are various inconveniences to this framework. Right off the bat, following marriage, the woman isn't allowed to choose her new nationality and the new nationality is forced on her occasionally without her assent. Accordingly, the woman may decline to wed an outside individual or goes into a casual association with the man. Besides, from the statistic strategies perspective, this hypothesis leaves a negative impact on the number of inhabitants in nationals of a nation particularly in nations with negative populace development. The explanation is that when the nationality of a remote man is forced on a lady, the number of inhabitants in ladies and their kids in the nation decreases.

Nevertheless, the pace of marriage of national men with remote women is extremely low since men move more than women. In this manner, the likelihood of marriage of remote men with national women is higher than marriage of outside women with national men. Thirdly, when the administration concedes the nationality of outsiders who solicitation the nationality of a nation because of their affection for their mates, however do not have any enthusiasm for the goal nation, it is viewed as a national risk to the security of the nation. The equivalent likewise applies to women who lose their country nationality in light of marriage (Badaqi, 2004).

There are various perspectives on the lawful wellspring of the post-marriage change in women's nationality.

women will can change the nationality: Advocates of this perspective accept that a woman acknowledges the nationality of her significant other in light of the fact that she needs to do as such. At the hour of marriage, the woman realizes that her significant other has the nationality of another nation and along these lines acknowledges the nationality of her better half with mindfulness and comprehension. Consequently, the essential nationality of the man is moved to the woman and not the ensuing nationality of the man that may result from the marriage. The woman is likewise mindful of the nationality at the hour 
of marriage. There are reactions on this perspective as the pundits accept that this thinking is not solid. Truth be told, the adversaries contend that if a lady acknowledges the nationality of her better half by her very own will, she ought to have the benefit to deny it as well. Notwithstanding, this is not valid and a woman cannot deny the nationality using all means. Backers of this hypothesis contend that when a woman acknowledges a man she is by implication tolerating his nationality as well. Consequently, they accept a nonexistent will is associated with this procedure.

Nevertheless, this thinking can be restricted by saying that through and through freedom possibly exists when you can express it and hence it can't have a fanciful presence.

Change of woman's nationality because of the man's strength: Advocates of this perspective accept that as man's predominance assumes a significant job in conjugal life and as the man is the leader of the family, along these lines the nationality of man is forced on the woman in view of man's need. There are likewise various reactions on this hypothesis and the adversaries accept that by discussing man's predominance over the woman or an absence of such strength we are in certainty entering the domain of private law, yet nationality is one of the ideas of general law. In addition, if the spouse's predominance is the prerequisite, in this manner his strength ought to likewise apply to the progressions made in his ensuing nationalities (Nazif, 2009). In any case, the difference in nationality in view of marriage happens at the hour of marking the marriage accord.

Change of woman's nationality because of marriage: Dr. Nasiri accepts that the adjustment in a woman's nationality is neither intentional nor inadvertent. It additionally does not result from the strength of her better half. He accepts that the difference in nationality is "the aftereffect of consenting to the marriage arrangement". As it were, governments that require the adjustment in the woman's nationality after marriage think of it because of marriage. In other words, when a woman is hitched, she acknowledges the marriage foundation as it is set up in her better half's nation. Clearly, a woman who gets hitched with her own assent is consequently tolerating the characteristic or unavoidable outcomes of the marriage including the inconvenience of her significant other's nationality on her. She in reality acknowledges the entirety of the lawful impacts of the marriage. By tolerating, the thinking the insufficiency of any ensuing changes to the spouse's nationality is likewise clarified (Arafnia, 2012). 4. Change of woman's nationality in line with the administrator: In this hypothesis, the spouse's nationality is forced on the wife because the lawmaker of the nation directs it to ensure the political and national interests of the nation.

In other words, the lawmaker of each nation predicts and sets a few conditions for marriage among outsiders and neighborhood nationals to secure the national interests of the nation. The ideas and subjects of private law and marriage law cannot be stretched out to the issue of nationality. To secure political interests, each family ought to be controlled by one nationality. Without meaning to embarrass one of the mates or disregard the fairness of rights, the lawmaker chooses to move the spouse's nationality to the wife to ensure the solidarity of nationality in families (Madani, 2008). Henceforth, in this view, nationality is an idea that is free of the thought of marriage and its burden or absence of inconvenience is controlled by governments.

Accordingly, a legislature may choose to force the nationality of the spouse of the wife, yet another administration may decline to do it. Lawful frameworks that put stock in the solidarity of nationality for couples, make a qualification between the case where an outsider lady needs to wed a man of nearby nationality and the case in which a lady of neighborhood nationality needs to wed an outsider man. Concerning women's nationality, lawful frameworks have given four characterizations that are examined in the accompanying. An) In this legitimate framework, which is known as the "relative freedom framework", when an outside woman weds a neighborhood man, the spouse's nationality is forced on the wife paying 
little respect to the law in the woman's country. At the end of the day, the outside woman consequently gains the nationality of the neighborhood man.

In addition, after the spouse's nationality is forced on the woman (and much after the marriage understanding is ended) the woman still has her previous husband's nationality except if she requests dropping of the nationality and recovery of her essential nationality after end of the marriage inside the fitting legitimate system. Nevertheless, when a nearby woman weds a remote man the guidelines administering the spouse's nation are applied. Thus, if the law governing the spouse's nation forces husband's nationality on the woman, the woman loses her essential nationality (Nasiri, 2007). At the end of the day, when a nearby person weds an outsider man, loses her essential nationality just depending on the prerequisite that she acquires the nationality of her better half.

Such a woman will keep on living with the nationality of her better half and can just obtain her essential nationality after end of the marriage. Thusly, such a framework applies the "relative autonomy of nationality" standard to its nearby women. B) In this legitimate framework, at the hour of forcing nationality, the standard overseeing the woman's country is applied and at the hour of repudiating the nationality the standard administering the man's country is applied. In other words, when a remote woman weds a neighborhood man, she just gains her better half's nationality depending on the prerequisite that she abandons her own nationality because of their marriage. Overall, the woman gains the nationality of her significant other, and as she relinquishes her very own essential nationality the nationality of her better half is forced on her. In the lawful frameworks that pursue this guideline, the spouse's nationality is forced on the wife just if the woman loses her essential nationality in view of the marriage. As it were, in this gathering of lawful frameworks, the standard overseeing the woman's nation is actualized when it is important to force the spouse's nationality on the woman. The primary way of thinking behind this technique is to anticipate statelessness of the woman. In other words, if a woman loses her essential nationality because of the marriage and she likewise neglects to win the nationality of her significant other, she stays stateless. Another theory behind this guideline is to anticipate "double nationality" because of positive logical inconsistency of laws provided that the spouse's nationality is forced on the wife and the lady's country additionally still thinks about her among its nationals, at that point the lady has double nationality.

In such frameworks, when a national woman weds an outsider man, she just loses her nationality relying on the prerequisite that she gains the nationality of her better half and educates the administration regarding her country of the adjustment in her nationality through lawful proper strategies (Hemmat, 2011).

In this lawful framework, the guidelines overseeing the woman's country are utilized to force nationality. At the point when an outside woman weds a neighborhood man, she wins the nationality of her significant other gave that she abandons her essential nationality because of her marriage. This lawful framework is fundamentally and like the framework clarified in passage in this supposition. In any case, the contrast between this legitimate framework and the one clarified in section is that in the framework clarified in passage when a remote woman weds a nearby man however keeps her nationality, she can procure the nationality of her significant other after marriage and on some particular condition. Notwithstanding, in the legitimate frameworks clarified in passage there is no law on this circumstance and the woman keeps her essential nationality. The explanation is that these legitimate frameworks do not perceive double nationality by which the woman keeps her essential nationality and furthermore wins her better half's nationality simultaneously.

Nevertheless, when a nearby woman weds an outside man she has the privilege to dismiss her essential nationality. A nearby woman who weds a remote man keeps her essential nationality except if she needs to end it. The woman is conceded with the unqualified right to dismiss her essential nationality and if 
a woman chooses to this she needs to educate her country government through lawful proper methods. In this kind of legitimate frameworks, when a neighborhood woman weds a remote man, the woman is yet viewed as a national by her country nation paying little respect to the guidelines administering the man's nation.

In this manner, the main factor that can deny the person of her essential nationality is her own dismissal of her nationality and her solicitation for asking her better half's nationality. This gathering of legitimate frameworks does not have any significant bearing the rule of "solidarity of nationality in family" when the lady is a national and the man is an outsider (Ibid).

In these lawful frameworks, the remote woman procures the nationality of the man's nation just on the off chance that she meets the living arrangement condition or their marriage understanding goes on for a particular timeframe. In such frameworks, when a nearby woman weds an outside man, she can abandon her nationality in the event that she lives in another nation. As it were, this woman is conceded the "right to dismiss her essential nationality" by just depending on the prerequisite that the couple live in an outside nation together (Raeesi, 2011).

Legitimate Systems Opposing the Imposition of Husband's Nationality on the Wife In the discourses of ladies' privileges the most conspicuous school that supporters restoration of ladies' privileges is the "women's liberation school". Women's liberation is a word that alludes to "the clique of spreading ladies' privileges and jobs in the general public". Largely, it very well may be said that speculations of woman's rights result from a progression of concentrates on women that verifiably or unequivocally propose a general far reaching scholarly arrangement of the key qualities of ladies' public activity. These speculations have basic and dynamic methodologies that advantage women and attempt to improve a world for women. These hypotheses hold that a superior world for women improves a world for the entire humanity.

Examination of various indications of "separation by sex" uncovers that one of the most significant instances of this type of segregation is "separation on the grounds of nationality". Separation on the grounds of nationality is an unequivocal type of segregation that expressly awards benefits to men that are not allowed to women and denies women of those advantages. With the headways of this school and the scholarly endeavors made in various social orders, the issue of women's autonomy has pulled in across the board consideration since the mid twentieth century. Thus, because of the various endeavors and demands by women and developments pushing women's privileges various governments gave total opportunity to women and conceded them equivalent rights as men.

In this manner, they additionally made changes to their laws on family and couples nationality (Ebadi, 2006). As per this hypothesis, a lady can wed a man with a nationality not the same as hers without tolerating the man's nationality after the marriage. Subsequently, it is said that at the hour of marriage the woman just becomes hopelessly enamored with the man and not his nationality. Accordingly, the marriage has no impact on the couple's nationality and particularly the woman's nationality. Thusly, the woman's nationality isn't changed naturally by the marriage. In any case, so as to help family and solidarity of family, offices are given to the couple with the goal that every one of them can pick the nationality of the other mate intentionally. The benefit of the supreme freedom framework is that it permits women wed remote men without having stresses over the inconvenience of the spouse's nationality on them. In addition, marriage of a neighborhood with an outsider does not roll out any improvements to the nation's populace as well. In any case, regardless of the previously mentioned focal points, this framework likewise has drawbacks. For instance, in this framework a solitary legitimate framework doesn't manage the family and the family's organization may be upset whenever. In addition, the likelihood of double nationality for the youngsters heightens if the kids' nationality framework is influenced by their maternal or fatherly side or the two sides. 
Likewise, when the relations between two nations arrive at a basic point or a war begins, restrictions are forced on outside occupants in the included nations. The imperatives can undermine the solidarity of families and impressively increment the odds of contradiction on the standards and guidelines influencing couples (Mehrpour, 2011). In spite of the fact that the likeness between all these legitimate frameworks lies in the way that they do not force the spouse's nationality on the wife, they can be arranged into three significant gatherings. An) In this gathering of lawful frameworks which are known as the "outright freedom of nationality" frameworks, when an outside lady weds a nearby man, she doesn't secure the nationality of her significant other. Likewise, when a nearby woman weds a remote man, she does not lose her essential nationality.

In this methodology, women's liberation calls for fairness of people concerning the issue of nationality. In this manner, it totally isolates marriage from nationality and subsequently marriage has no impact on nationality of individuals. This methodology prompts the refutation of solidarity of nationality of couples. Accordingly, every one of the mates goes into the marriage and lives with his/her mate with their own essential nationality. B) In this lawful framework, when an outside woman weds a nearby man, she doesn't consequently get her significant other's nationality however she can gain through a requestor through brief desk work (Imani Naeeni et al, 2011).

Also, when a neighborhood lady weds a remote man, she just loses her essential nationality depending on the prerequisite that she dismisses it. In these total lawful frameworks, the lessons and standards of woman's rights just as equivalent rights for people administer the idea of nationality. In like manner, any impact of marriage on nationality is dismissed and the key factor in this procedure is the will and assurance of women to choose their nationality without tolerating a nationality that is forced on them through marriage. In this gathering of legitimate frameworks, because of blended marriage, which does not require solidarity of nationality for couples, the lady (either neighborhood or outsider) is permitted to keep her essential nationality. This applies to an outside woman who weds a neighborhood man and a nearby woman who weds a remote man.

In this legitimate framework, an uncommon and favored methodology for procuring nationality is utilized. The "unique and special strategy" for procuring nationality is a technique wherein a remote lady who weds a neighborhood from a nation running these lawful frameworks needs to meet a few criteria like the criteria for different outsiders (for example dwelling in the goal nation) to have the option to procure the nationality of her significant other. As such, she ought to live in the objective nation for some time subsequent to winning her significant other's nationality. She likewise needs to meet other criteria that are clarified in subtleties and completely with the nationality laws of these lawful frameworks. The third framework is likewise arranged into four distinctive sub-classes.

At the point when a portion of the criteria for procuring nationality are applied to the individual and the living arrangement time is likewise diminished in certain nations that run this legitimate framework, the remote lady who needs to wed a nearby man should meet a few criteria, for example, the criteria for different outsiders to have the option to obtain the nationality. In any case, a few criteria and conditions including the home condition are exemptions and the living arrangement time frame is decreased for the lady (Al Kajbaf, 2010).

At the point when the entirety of the criteria for procuring nationality are applied to the individual and the living arrangement time is additionally diminished in certain nations that run this lawful framework, an outside lady who needs to wed a neighborhood man should meet the entirety of the conditions, for example, the conditions for different outsiders to have the option to gain the nationality. The main exemption is the habitation time frame, which is diminished for this lady. 
At the point when the individual is obliged to meet the home rule and have a comprehension of the goal nation's authentic language in nations following this guideline, a remote lady that weds a nearby man should meet the living arrangement standard and have great learning of the goal nation's legitimate language so as to have the option to secure the ideal nationalit (Saljuqi, 2009).

\section{Conclusion}

At the point when the individual is obliged to meet the living arrangement paradigm to procure the nationality. In certain nations, an outside lady who needs to wed a nearby man should just meet the living arrangement foundation to have the option to gain her significant other's nationality (Kar, 1999). End Among the previously mentioned lawful frameworks, the most attractive framework that consents to the essentials and nuts and bolts of human rights is the legitimate framework wherein the spouse's nationality isn't forced on the lady if an outside lady weds a neighborhood man. In this framework, the woman can get the nationality of her significant other by making a solicitation or experiencing brief administrative work. In addition, in this framework, if a nearby woman weds an outside man, the woman is conceded with the privilege to dismiss her essential nationality. This framework not just anxieties the autonomy of marriage from nationality and rejects any sexual orientation segregation among women and men, yet additionally saves the woman's nationality after her union with a remote man. Furthermore, so as to secure the solidarity of family, this framework allows the lady the privilege to dismiss her essential nationality and get her better half's nationality.

\section{References}

Al Kajbaf, H. (2010). Nationality in Iran and other countries. Jangal Press, pp. 188-189.

Arfania, B. (2012). Private International Law.Vol. 1, Behtab Press, 4th edition, p. 88.

Azimzadeh Ardebili, F.,Khosravi, L. (2009). Acomparative study of women's rights from the viewpoints of Islam and the West (4). Centre for Family and Women's Affairs.Presidency Office, 1th edition, p. 86.

Badaqi, F. (2004). Marriage and nationality of Iranian women. Women's Book, Tehran,Women's CulturalSocial Council, no. 24,p. 129.

Department of Economic and Social Affairs ofUnited Nations, "Nationality of Married Women", New York, United Nations Publication, 2006.

Ebadi, S. (2006). Women's right in the Islamic Republic of Iran's legislation. Ganj-e Danesh Press, 2nd edition, p. 163.

Golshanpazhuh, M. (2008). The guide to humanrights in international communities (mechanisms and processes). Abrar Mo'aser Publications, 1th edition, p. 50.

Hemmat, M. (2011). Change of nationality dueto marriage. Islamic Azad University,Research and Science Branch, pp. 120-121. 
Imani, N. (2011). Feasibility study of theexpansion of legal supports for the marriage of women with foreign men. Women's Strategic Studies, Quarterly of the Cultural and Social Council for Women and Family.No. 54, 14th year, winter 2011, p. 113.

\section{Copyrights}

Copyright for this article is retained by the author(s), with first publication rights granted to the journal.

This is an open-access article distributed under the terms and conditions of the Creative Commons Attribution license (http://creativecommons.org/licenses/by/4.0/). 